\title{
DE ZEVEN BRONZEN VATEN (IN GEZELSCHAP VAN EEN BI)
}

ZOALS BELOOFD IN het tentoonstellingsbericht 'Zeven bronzen vaten en een bi', in het December-nummer van Aziatische Kunst, komen we hier terug op de bijzondere bruikleen uit de Chinese collectie van de Arthur M. Sackler Gallery in Washington, D.C., die enkele maanden lang onze Amsterdamse zalen heeft gesierd. Na de Neolithische bi, die de vorige keer al is besproken, volgt ditmaal het brons: zeven stuks bronzen vaatwerk, daterend van de 13e eeuw v.Chr. tot het begin van onze jaartelling.

DE EERSTE INDRUK, van de opstelling in zaal 5, was die van een rijtje atleten in topconditie. Stuk voor stuk stralend, en perfecte vertegenwoordigers van hun soort. Brons op zijn mooist. Sommige zo 'scherp' en fris alsof ze gisteren gegoten zijn, andere juist met de toegevoegde esthetische waarde van een blauwgrijs, lindengroen, roodbruin of malachiet-kleurig patina.

Het tweede effect was de verrassing die je dikwijls overvalt bij het zien van voorwerpen die uit afbeeldingen al heel vertrouwd zijn. In het echt blijken ze dan ineens veel groter of veel kleiner dan verwacht, en om de een of andere reden is dat vooral bij dergelijke bronsvaten vaak het geval. Waarschijnlijk komt het doordat aan de vormen en de decoratie van dit rituele vaatwerk 'wetten' ten grondslag liggen die niet of pas in de laatste plaats betrekking hebben op hun directe, uiterlijke verschijningsvorm. De detaillering neemt niet toe of af met het formaat, en de visuele impact is daardoor onafhankelijk van zoiets als 'schaal'.

\section{Brons}

HET BRONZEN VAATIVERK werd gegoten in een z.g. samengestelde (of 'gesegmenteerde') gietvorm, gemaakt van gebakken klei. Het 'samenstellen' van de gietvorm was een gecompliceerd proces, dat het vervaardigen inhield van een negatieve mal (gevormd rond een positief model), verdeeld in segmenten die precies passend weer konden worden samengevoegd (na verwijdering van het model). Daarbinnen kwam ten minste één 'kern' van klei, die de binnenvorm bepaalde, voor het bassin, de holte van het vat, maar meestal waren er meerdere kernen nodig: voor een holle voet, voor de ruimte tussen de poten, het gat van de oren, etc., al naar gelang het type. De delen werden gebakken, en bij elkaar gevoegd. Tijdens het gieten zorgden kleine wiggen, gemaakt van stukjes (afval-)brons, voor een regelmatige afstand tussen kern en buitenvorm - en tussen kern en kern, bijvoorbeeld om de ruimte voor een bodem open te houden tussen de kern-delen voor bassin en voet.' Ingewikkelde vormen vereisten ook vaak het vooraf gieten van bepaalde onderdelen, zoals poten, of de afzonderlijke zijkanten van een rechthoekig vat, die dan (in brons) ingevoegd werden in de klei-vorm voor het geheel, en zo 'aan'gegoten werden aan derestivan het datir En voor cen/2023 12:59:54PM 
kunststukje als een ketting-hengsel (aan latere bronzen, zoals hier de platte fles in afb.6) moest een extreem gecompliceerde, stapsgewijs uitbreidende reeks van mallen en opeenvolgende gietsels worden bedacht en toegepast. In het gietproces kreeg een brons niet alleen zijn vorm, het kreeg ook zijn versiering. De decoratie in reliëf werd niet achteraf gegraveerd, maar was, al voor het bakken, eveneens negatief in de klei van de gietvorm aangebracht. Ze werd hetzij direct aan de binnenzijde van de losgesneden segmenten ingekerfd - de eenvoudigste en vroegste methode, die een patroon van enkelvoudige, verhoogde lijnen oplevert in het voltooide brons; hetzij, op den duur, verkregen door middel van een plastisch geheel uitgewerkt en gedetailleerd model - wat de mogelijkheid bood van grotere volumes, en een combinatie van intaglio patronen mèt (en vooral ìn) het hoogreliëf. Bij deze methode werd de decoratie dus tegelijk met de hele vorm overgebracht in de klei van de mal.

De allervroegste lijndecoraties zijn hier niet aanwezig, maar vergelijking van het reliëf op de eerste twee voorbeelden in de Sackler-selectie, uit de Shangdynastie (ca 1500 -ca 1050 v.Chr.) met enkele eeuwen verschil tussen de beide vaten, toont iets van de geleidelijke ontwikkeling en (letterlijk) verdieping van het technisch repertoire door de vroegste generaties van bronsgieters ( $a f b .1$ en 2 ).

\section{Brons was zowel resultaat als manifestatie - en daarmee ook symbool - van macht.}

DE PRODUCTIE VAN brons was voorbehouden aan koningen en adel, want allereerst vereiste het macht: de macht om de kolossale hoeveelheden mankracht te kunnen mobiliseren en organiseren die nodig waren voor het opsporen van de bronnen en het winnen van de ertsen - koper, tin, en lood; voor het transport, het smelten, de legering, en tenslotte de technologie van het gieten, inclusief het keramisch vakmanschap dat vereist was voor het maken van de gietvormen, volgens het hierboven beschreven proces. Het verschafte de reële macht van bronzen wapens, maar minstens zoveel tijd en moeite werden besteed aan het maken van het bronzen vaatwerk, waarin voedsel en drank werd geofferd aan de voorouders. De offerrituelen moesten de voorspoed en het voortbestaan bewerkstelligen van degenen die ze uitvoerden, en in die zin waren het ook wapens, die het rijk en het koningshuis beschermden tegen boze machten, rampen en kwalen.

Het machts-aspect van brons werd expliciet toen rond $1050 \mathrm{v}$.Chr. de laatste koning van Shang werd verslagen, en opgevolgd door de heren van Zhou, een volk dat zich had gevestigd ten westen van het Shang-rijk. De koningen van Zhou verleenden land en volgelingen aan hun vazallen, in een min of meer 'feodaal' systeem, en daarbij fungeerden giften van brons en bronzen vaten als beloning en bezegeling van de overeenkomst. In $770 \mathrm{v}$.Chr. moeten koning en hoofdstad, gedwongen door invallen van barbaren, naar het oosten verhuizen - en dat is het einde van de z.g. Westelijke Zhou, de eerste helft van de Zhou-dynastie. In de Oostelijke Zhou is van de oppermacht van de koning weinig overgebleven, de feodale domeinen vallen uiteen in een groot aantal steeds onafhankelijker wordende staten en staatjes - elk met hun eigen werkplaatsen voor bronsproductie, en hun eigen offervaten. 


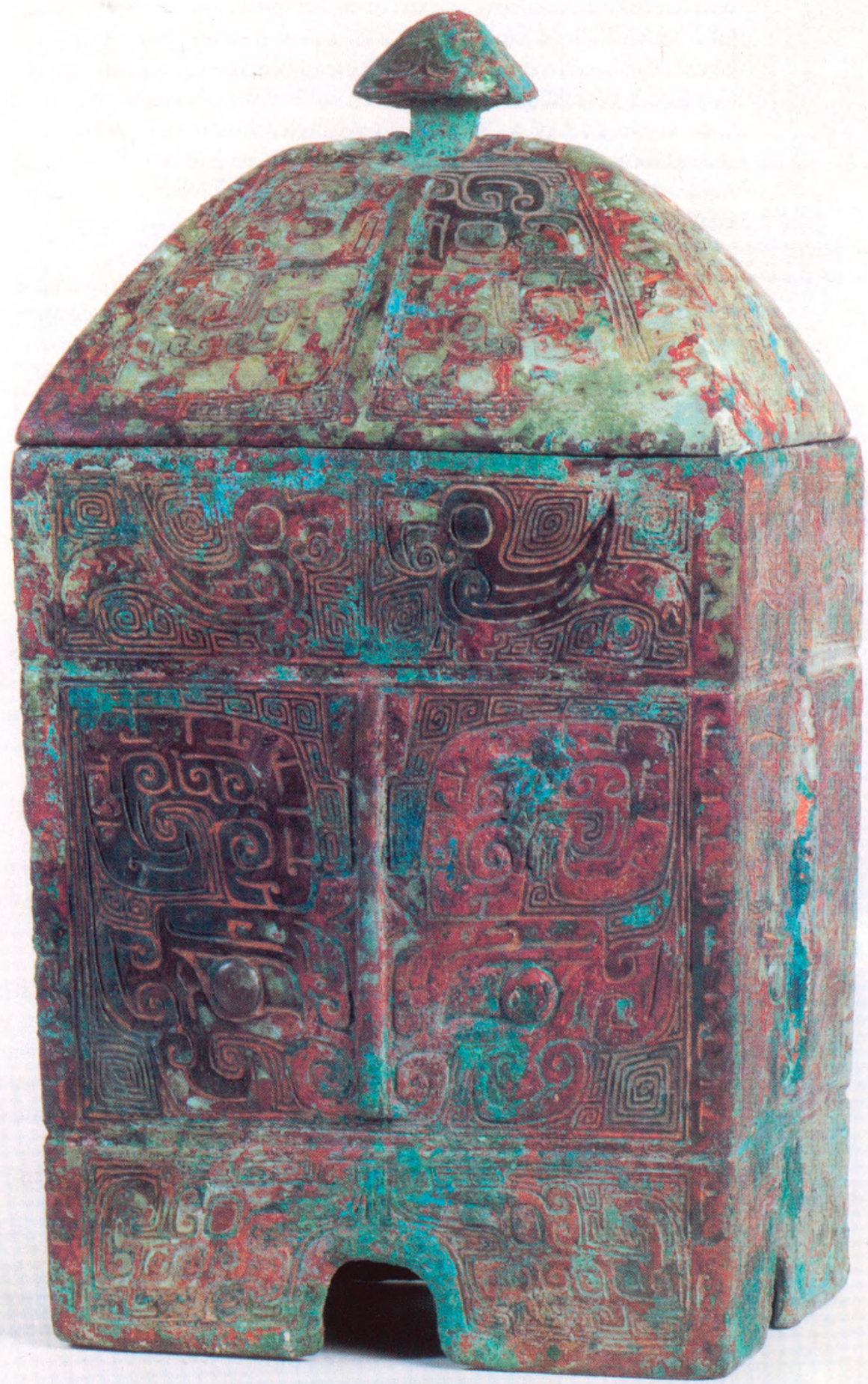




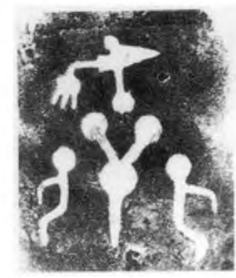

Afbeelding 1 (links) Rechthoekig bronzen wijnvat met deksel, fang yi, China, Shang dynastie, 13e eeuw v.Chr., $18,4 \times 11,1 \times 8,1$ cm. Arthur M. Sackler Gallery of Art, Smithsonian Institution, Washington D.C., schenking van de Arthur M. Sackler Foundation. S1987.34a-b.

Afbeelding ra (boven) Inscriptie in fang $y$ i: 'Bei Dan Ge'.

\section{Offervaten}

Het bronzen vaatwerk werd gebruikt in rituele banketten; er werd drank en voedsel in verwarmd, en waarschijnlijk nadat dat gedeeltelijk ook zelf geconsumeerd was, werd het aangeboden, geofferd aan de (koninklijke) voorouders. Over de rituele praktijk van de Shang en de Zhou is weinig of niets concreet bekend, maar de handelingen in het ritueel bepaalden de samenstelling en vormen van het offergerei, zoveel is wel duidelijk. Veranderingen in het ritueel zijn af te lezen uit veranderingen in de verzameling en de aantallen van de verschillende typen vaten. Er komen nieuwe typen bij, en andere soorten verdwijnen. Opvallend is bijvoorbeeld dat, al vrij kort na het begin van de Zhou-dynastie, in de graven nauwelijks nog vaatwerk voor wijn wordt aangetroffen. Social drinking speelde al een grote rol in de Neolithische culturen van oostelijk China, en de Shang heeft dat voortgezet, met de specifieke vormen van schenk-, pleng- en drinkbekers, en grote en kleine opslagvaten. Maar kennelijk deelde de Zhou, met hun (westelijke) afkomst die traditie niet; de wijnvaten verdwijnen, evenals - mag je aannemen - het bijbehorend ritueel.

De vaten functioneerden dus uitsluitend als onderdeel in een reeks, dat wil zeggen: een bepaalde combinatie, van bepaalde typen vaatwerk, in bepaalde aantallen, die voor een persoon of familie in die bepaalde tijd nodig waren voor de uitvoering van de passende rituelen ten behoeve van de voorouders. En zo worden ze dan ook meestal gevonden, in functionele 'sets', als een $\mathrm{X}$-delig servies. Hetzij in graven (om ervoor te zorgen dat de overledene ook daar zijn offerplichten kon blijven vervullen), hetzij in grote opslagkuilen: misschien eens de voorraadkamer bij een tempel - of het zijn de haastig in veiligheid gebrachte schatten van een feodale heer die zijn residentie moest verplaatsen, want dit waren onrustige tijden.

MET ANDERE WOORDEN: één bronsvat in een vitrine (en zeven geïsoleerde bronsvaten in gezelschap van een $b i$ ) zijn eigelijk van hun ware betekenis ontdaan - maar zolang we dat maar beseffen, mogen we genieten van hun schoonheid:

- Rechthoekig bronzen wijnvat met deksel, fang yi (afb. 1)

Shang-dynastie (ca 1500-ca 1050 v.Chr.), 13e eeuw v.Chr.

Een BetRekKelijk KLEIN vat, met ondiep reliëf in drie registers. ${ }^{2}$ Aan alle vier de zijden vullen gehoornde taotie 'monster'koppen het middelste register, steeds in twee symmetrische helften, gescheiden door een licht verhoogde middenrib; in de bovenrand staan kleine vogels met grote ogen in paren tegenover elkaar, en op de voetrand lopen draken, eveneens gepaard. Op de smallere zijkanten zijn de figuren passend verkleind of gecomprimeerd. De achtergrond is steeds zorgvuldig opgevuld met spiralende meander-blokjes (het z.g. 'dondermotief', leiwen). Het deksel vertoont, eveneens tegen een leiwen achtergrond, alleen vier taotie, ondersteboven - hetzij omdat het motief op deze manier beter paste in de beschikbare ruimte, hetzij opdat de monsters een over het vat gebogen celebrant zullen aankijken.

De bodem van het vat bevindt zich ter hoogte van de lijn boven het onderste register, maar dat is van de buitenkant niet zichtbaar of zelfs te vermoeden. In de vroegste voorbeelden van fang yi die bekend zijn, springt de wand van het vat onder de bodem in. Daar is dus sprake zan een duidelijkeovoet, een 12:59:54PM 
rechthoekige versie van de ronde voetring onder een vergelijkbaar rond wijnvat. Vrijwel alle vormen van het rituele bronzen vaatwerk hadden hun directe voorlopers in het (Neolithisch) aardewerk, en waarschijnlijk werden aardewerk en brons ook in de offerpraktijk van de Shang nog steeds wel zij aan zij gebruikt. Rechthoekige (fang) varianten moeten daarom aanzienlijk meer prestige hebben verleend dan ronde, aangezien een dergelijke vorm niet anders dan van (het kostbare) metaal vervaardigd kon zijn, en als zodanig ook direct herkenbaar was. De doorlopende wanden maakten dat waarschijnlijk nog duidelijker.

IN DE BODEM van het vat, aan de binnenzijde, en in de opstelling dus onzichtbaar, bevindt zich een inscriptie gegoten in intaglio ${ }^{3}$ ( $a f b$. la): het is een embleem dat gevormd wordt door het karakter ge, een hellebaard met kwast, boven een teken dat als dan wordt gelezen, geplaatst tussen de twee helften van het karakter bei (Noord) - twee mensfiguurtjes met de ruggen naar elkaar gewend. Bei Dan is vermoedelijk een plaatsnaam, en komt voor in orakelteksten (in botten en schildpadschalen gekerfd), zowel als in bronsinscripties van de Shang. De combinatie Bei Dan Ge is aangetroffen in ten minste negen bronsvaten, waaronder één paar en zeven van verschillend model (inclusief deze fang yi). Naar de stijl te oordelen, stammen alle negen uit dezelfde periode. Ze zijn wellicht gegoten in het tijdsbestek van een enkele generatie voor de clan die met dit embleem werd aangeduid. Van slechts drie van deze vaten is de herkomst bekend, maar aangezien het graf geplunderd was, is het niet ondenkbaar dat de overige zes oorspronkelijk eveneens uit dit graf afkomstig zijn. ${ }^{+}$

\section{Afbeelding 2 (rechts) Bronzen drievoet voor voedsel, li ding, China, Shang dynastie, 12e-11e eeuw v.Chr., 19,9 × 15,7 $x 15,8 \mathrm{~cm}$. Arthur $M$. Sackler Gallery of Art, Smithsonian Institution, Washington D.C., schenking van Arthur M. Sackler. S1987.12. \\ Afbeelding $2 \mathrm{a}$ (onder) Inscriptie in li ding: 'Bo Gong Zuo'.}

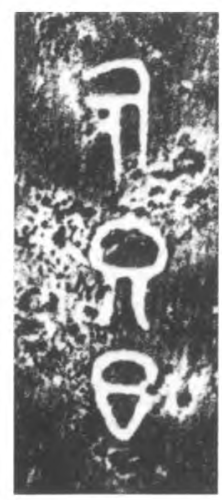

VAATWERK VOOR WIIN speelde een belangrijke rol in het ritueel van de Shang. Heel karakteristiek, en altijd in meerdere exemplaren vertegenwoordigd, zijn de plengbekers of schenkkannen (jue) met tuit, op drie pootjes verhoogd, ook voor het verwarmen van de drank, en de hoge, slanke drinkkelken (gu). Beide typen ontbreken helaas in deze selectie, maar zijn wel in de naburige vitrine te zien: twee jue (AK-MAK-1322) en twee gu (AK-MAK-8 en AK-RAK-1988-2).

\section{- Bronzen drievoet voor voedsel, li ding (afb. 2)}

Shang-dynastic, 12e-11e eeuw v.Chr.

HET RELIËF OP de kom van deze fraaie drievoet is buitengewoon complex, het is de meest ontwikkelde vorm van de Shang-decoratiestijlen - let bijvoorbeeld in de taotie op de extra uitkrullende punten van 'onderkaak' en hoorn, en op de randen van de bladvormige oortjes. ${ }^{5}$ Zelfs de cicades in de bovenrand, meestal een zuiver lineair motief, hebben afzonderlijk reliëf gekregen. De 'naturalistische' ribbeling op de hoorns van de taotie-koppen is uitzonderlijk, evenals de extra ribbelrand over de neusrug(gen) van het tweezijdige dier, aan weerskanten van de centrale flens-rib (op de lijn van de gietnaad, recht boven iedere poot). In de rand met cicades zijn nog drie korte 'flensjes' geplaatst, steeds halverwege tussen de grote. Overigens kan, door het extreme reliëf, dit vat soms merkwaardig scheef en asymmetrisch lijken, wanneer je het vanuit een 'verkeerde' hoek bekijkt.

DIT TYPE VAT, verhoogd op drie poten (of de zeldzamere rechthoekige fang ding, op vier poten, hier niet aanwezig) kon bovent een nuurtje worden/2023 12:59:54PM 


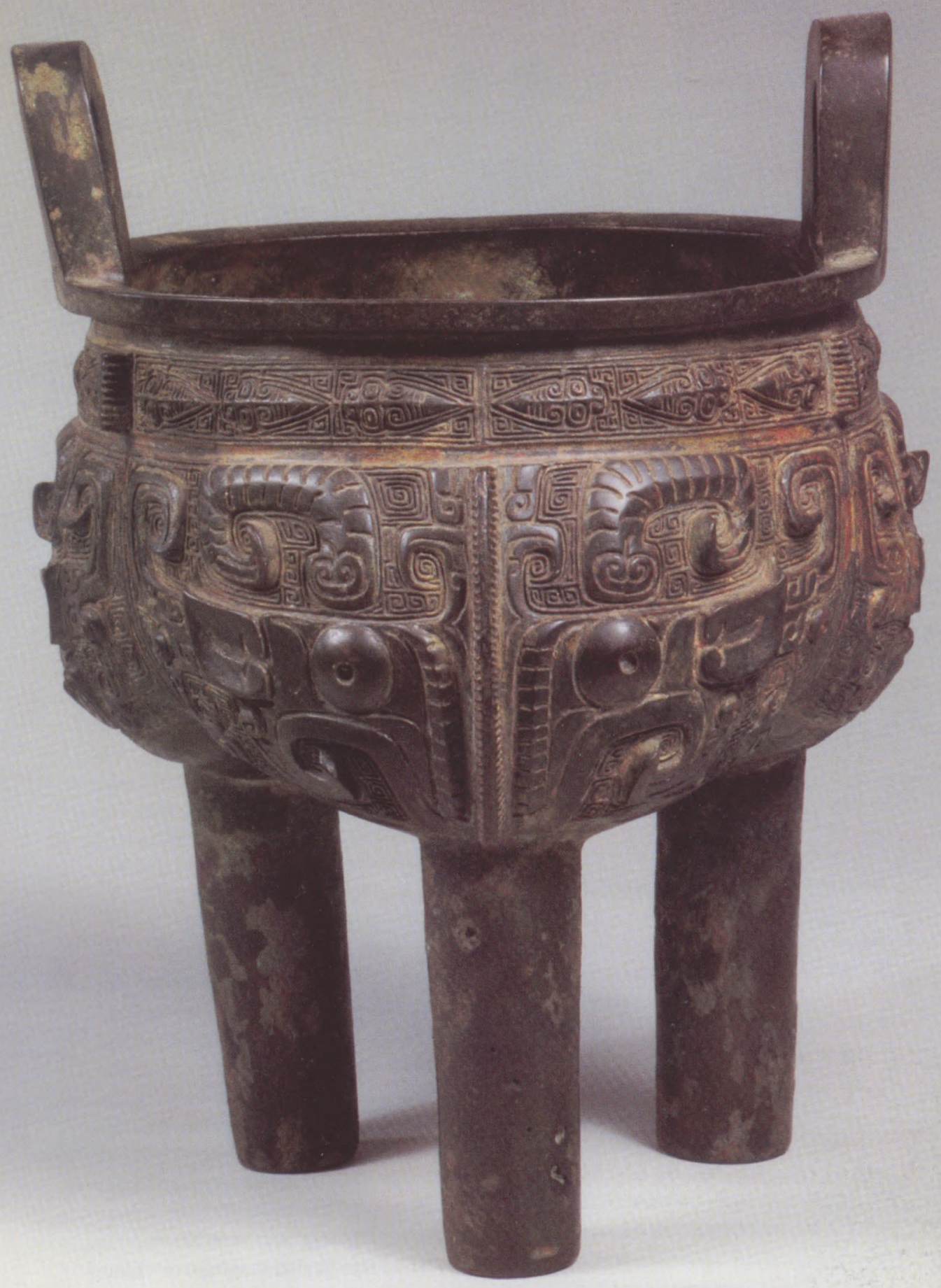


geplaatst, om het offervoedsel te verwarmen. De lichte bolling boven iedere poot in de buik van dit exemplaar rechtvaardigt de naam li ding, in plaats van gewoon ding: een ding heeft een vlakke bodem, een $l i$ is uitgesproken uiervormig - dit is dus een kruising tussen die twee (zie ook de tabel).

De poten lopen heel licht naar binnen, wat het vat een mooie 'trotse' houding geeft. Ze zijn glad, zonder versiering. Vergelijk de li ding in de Rijksmuseumcollectie (AK-RAK-1993-1), eveneens Shang, maar van waarschijnlijk iets latere datum, waar onder de kom aan de bovenzijde van de poten een hartvormig schildmotief naar beneden wijst, in enkele lijnen in intaglio aangebracht. Later, in de Zhou, zie je vaak op deze plaats een uitgebreide decoratie in hoogreliëf.

OOK DEZE DRIEVOET bevat een korte inscriptie, aan de binnenzijde in de wand van het vat - voor een museumbezoeker van gemiddelde lengte met enig rekken van de nek nèt te onderscheiden ( $a f b$. 2a). Bo Gong Zuo betekent 'gemaakt door Bo Gong' - maar dat wil niet zeggen dat de bronsgieter zijn werk heeft gesigneerd, het gaat hier zonder twijfel om de naam van degene voor wie het vat werd gemaakt, de opdrachtgever.

\section{- Bronzen offervat voor voedsel, gui (afb. 3)}

Westelijke Zhou-dynastie (ca 1050-771 v.Chr.), 11 e eeuw v.Chr.

HET VAT OOGT massief, en (in reproductie) veel imposanter dan de relatief kleine afmetingen lijken te rechtvaardigen. ${ }^{6}$ Hoewel elementen van de decoratie dezelfde zijn gebleven, heeft het een totaal andere uitstraling dan de bronsvaten van de Shang. Het is als geheel, met zowel het zware blok van de voet als ook de ribbeldecoratie, en vooral de stereotiepe vorm van de oren, bij uitstek typerend voor de vroege Westelijke Zhou.

Toch is het vierkante voetstuk, dat in deze tijd plotseling opduikt, waarschijnlijk niet zozeer een 'eigen' kenmerk van de stijl van Zhou, maar is het afgeleid van het (afzonderlijke) onderstel, sokkel of tafeltje - vaak van brons maar ook wel van steen - met plaats voor een of meer offervaten, dat al veel langer bekend is uit de Shang. ${ }^{7}$ De vernieuwing ligt dus vooral in het combineren van vat en onderstel tot een geheel.

DE RECHTLIJNIGE CANNELURES rond de kom worden boven en onder afgesloten met een fijn gedetailleerde versierings-band, onder de rand van het vat gevuld met tweemaal centraal een gehoornde dierenkop, waaraan een dubbel, kronkelend slangenlijf ontspruit, inclusief schubben, en rond de voetring met symmetrische, dunbelijnde 'vogel'figuren voorzien van kuif, haaksnavel en vervaarlijke klauwen. Beide randen hebben een achtergrond van leiwen-spiralen. Op de rechte zijden van de sokkel zijn smalle panelen van verticale ribbels omlijst door een drastisch gestileerd motief van hakenplus-oog, dat alleen nog heel in de verte verwijst naar zoiets als een 'draak' of 'vogel'. De oren van het vat vertonen bovenop een rundachtige dierenkop met grote hoorns, daaronder buigen zich vleugels op een vogellijf, en op de zware pendanten zijn aan beide zijden de haakvormige staart en een klauw van de vogel te onderscheiden.

Onderzoek heeft aangetoond dat in de oren en pendanten de originele kleikern nog aanwezig is. In de opstelling - maar helaas niet op de foto - is te zien dat aan beide kanten van de kom onder het oor de ribbels ontbreken,3 12:59:54PM 
Afbeelding 3

Bronzen offervat voor voedsel, gui, China, W. Zhou dynastie, ne eeuw v.Chr., $23,4 \times 30,0 \times 19,6$ cm. Arthur M. Sackler Gallery of Art, Smithsonian Institution, Washington D.C., schenking van Arthur M. Sackler. S1987.342.

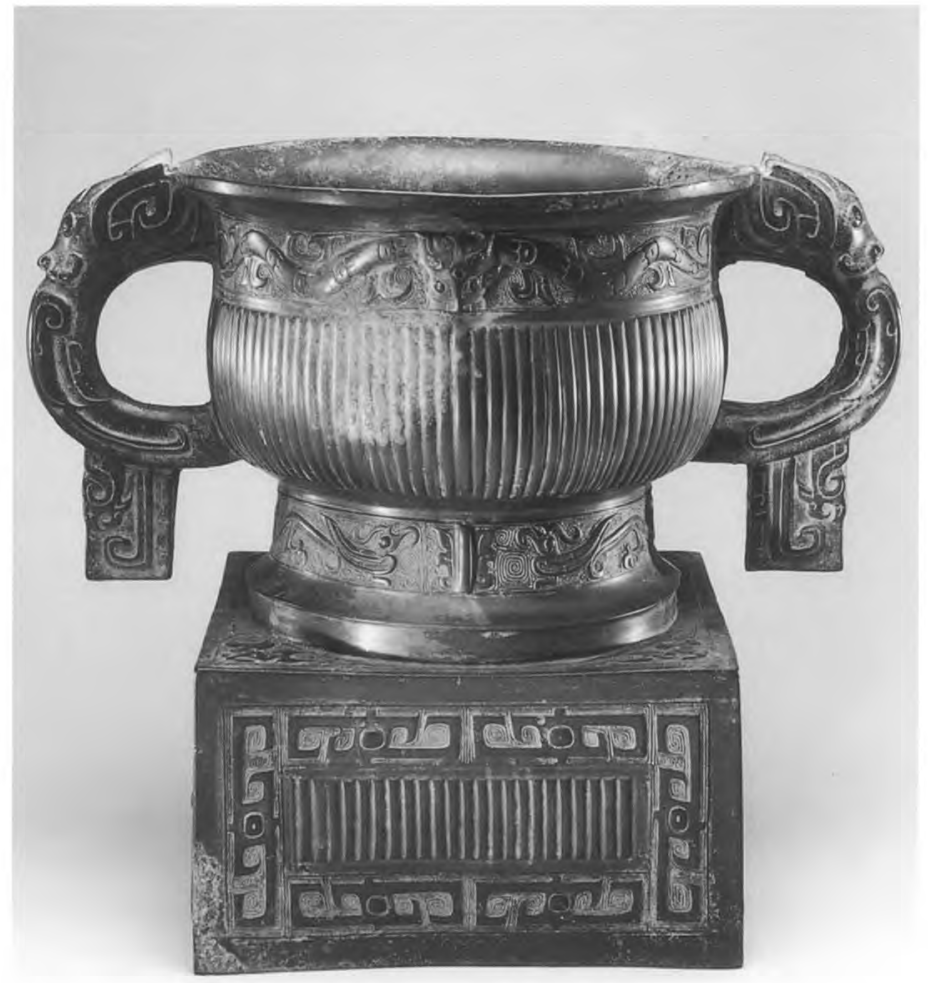

een smalle strip is daar onversierd gebleven. Met andere woorden: daar zat, bij het gieten, de halvemaan-vormige kern van klei voor het gat van het oor, en hier valt uit op te maken dat het vat in één keer gegoten is, de oren zijn niet in een tweede gietsel 'aan'gegoten.

DIt TYPE gui wordt talrijk in de tweede helft van de Westelijke Zhou, wanneer het aantal identieke vaten waarop iemand recht heeft (i.e.: de feodale heren onder de koning van Zhou), formeel als rang- of status-aanduiding gaat fungeren. ${ }^{8}$ Deze is relatief vroeg wat dat betreft, maar er zijn inderdaad twee andere, praktisch identieke vaten bekend, die dus misschien eens samen deel uitmaakten van zo'n offergarnituur, door de Zhou-koning aan een van zijn vazallen verleend. ${ }^{9}$

Afgezien van 'aantal als maatstaf voor rang', wijst de herhaling van een en hetzelfde model mogelijk ook op meer repeterende handelingen in de rituele praktijk van de Zhou.

De gui (mèt deksel bewaard gebleven) uit de late Westelijke Zhou, die permanent in het museum is te zien (AK-MAK-1266), hoort ook bij deze in veelvoud geproduceerde typen. ${ }^{10}$ De brede horizontale ribbels op dit vat, met een heel ander effect dan de verticale cannelures op de Sackler-gui, lijken juist weer terug te grijpen op aardewerk voorbeelden. Dat is geheel in tegenspraak met wat eerder werd beweerd over het prestige van een duidelijk 'metalig' uiterlijk (in verband met de rechthoekige fang-vormen), maar het is heel goed mogelijk dat hier sprake is van een bewuste 'retro'trend, waarbij de oude normen, van de Shang-voorgangers, worden afgewezen en verruild voor moderne - nòg oudere - uit het eigen verleden.dded from Brill.com@4/26/2023 12:59:54PM 

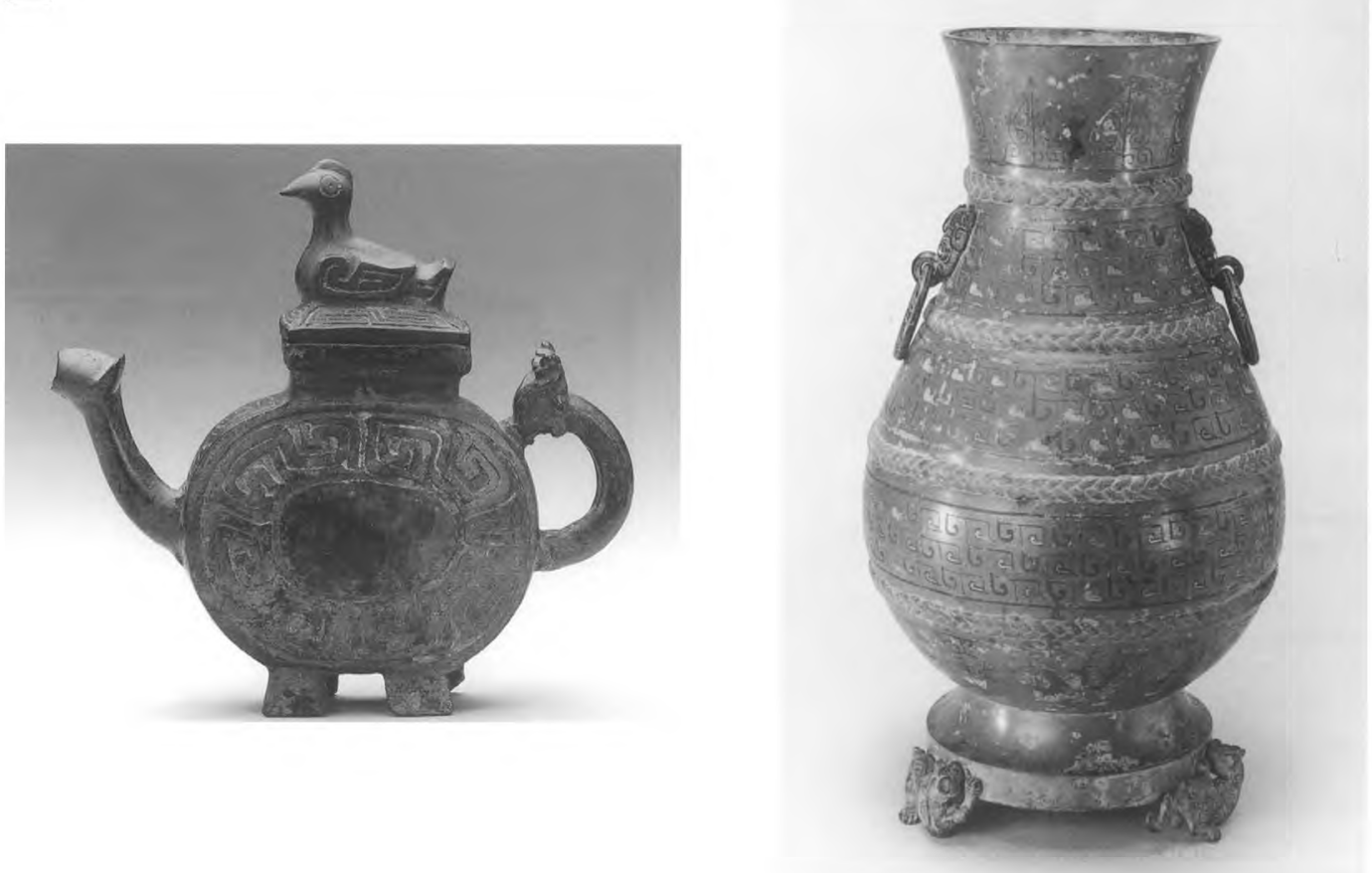

Afbeelding 4 (links) Bronzen (water)kannetje, he, met vogel op het deksel, China, W. Zhou dynastie, 950-850 v.Chr., $17,5 \times 19,7 \times 5,8 \mathrm{~cm}$. Arthur M. Sackler Gallery of Art,

Smithsonian Institution, Washington D.C., gezamenlijke schenking van de Arthur $M$.

Sackler Foundation, Paul Singer, de AMS Foundation for the Arts, Sciences, and Humanities, en de kinderen van Arthur $M$. Sackler. S1999.120.7.

\section{Afbeelding 5}

Bronzen wijnvat, $h u$, ingelegd met koper en goud, China, O. Zhou dynastie, 6e-se eeuw v.Chr., $43,6 \times 26,3 \times 16,8$ cm. Arthur M. Sackler Gallery of Art, Smithsonian Institution, Washington D.C., schenking van Arthur M. Sackler. S1987.318.

\section{- Bronzen (water)kannetje, he (afb. 4)}

Westelijke Zhou-dynastie, 950-850 v.Chr.

DE GRONDVORM VAN dit kannetje is rechthoekig, op vier stompe pootjes, het platte zijaanzicht is ovaal. ${ }^{12}$ Rondom de ovaal en op het deksel is een rand van brede meanders aangebracht, in merkwaardig vlakke lijnen en een flauw reliëf. De vogel op het deksel oogt ook tamelijk 'tandeloos', vergeleken met de haken en klauwen van eerdere soortgenoten. Zowel het uiteinde van de tuit als de aanzet van het oor zijn tot een soort schematisch aangegeven dierenkop gevormd, de laatste met spiraalvormige hoorns. Tuit en oor zijn waarschijnlijk na het gieten met soldeer aan het potje gehecht. Zoals wel vaker aan het eind van de Westelijke Zhou - een tanende macht van de dynastie lijkt hand in hand te gaan met een (bijna letterlijke) vervlakking van het ambacht - is het kannetje nogal grof uitgevoerd, in de zin van: schetsmatig en met weinig scherpte, maar het oppervlak is aantrekkelijk, met een zacht en glad groen patina.

Het is ook mogelijk dat het 'kleiige' uiterlijk niets met 'verzwakking van de ambachtelijke normen in roerige tijden' te maken heeft, maar dat het past in dezelfde trend die hierboven bij de Rijksmuseum-gui al is genoemd.

VAN DE he wordt verondersteld dat ze eerst, in de Shang en misschien nog de heel vroege Zhou, voor wijn hebben gediend, maar in de loop van de Westelijke Zhou veranderde hun functie. Van wijnkan werd de he waterkan, meestal als 'stel' geproduceerd en gebruikt, samen met een brede kom (pan), precies zoals 'onze' lampetkan en -kom.

Dit is een weinig gebruikelijk model, de meeste he lijken meer op het exemplaar dat in de tabel is afgebeeld. ${ }^{13}$ Downloaded from Brill.com04/26/2023 12:59:54PM 


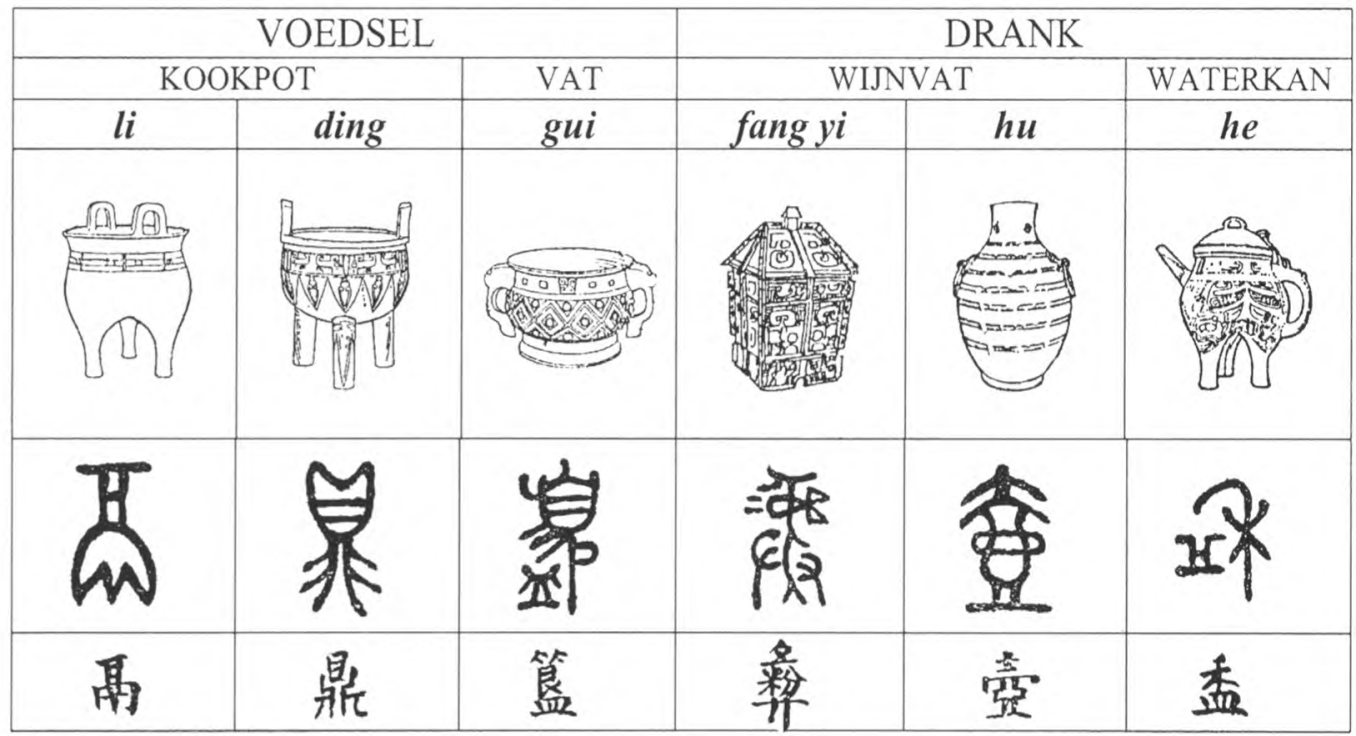

Tabel

Benamingen van de verschillende typen bronzen offervaten die vertegenwoordigd zijn in de bruikleen uit de Sackler Collecties, naar gebruik ingedeeld, met het oudste pictogram/ karakter en de moderne equivalent. (bewerkt naar de tabel in: W. Willetts, Foundations of Chinese Art, Londen, 1965, pp. 86 87)
- Bronzen wijnkruik, hu, ingelegd met zilver en goud (afb. 5)

Oostelijke Zhou-dynastie (770-221 v.Chr.), 6e-5e eeuw v.Chr.

EEN HOOG, PEERVORMIG rond vat met wijde hals, op een uitklokkende voet met geknikte voetring. ${ }^{14}$ Het voetstuk wordt gedragen door drie tijgers die met de bek en voorpoten de rand ondersteunen, het achterlijf neergehurkt. Vier vlechtbanden in reliëf verdelen het vat in vijf registers. Onder de band rond de hals hangt aan weerszijden een losse ring, vastgehouden door een monsterkop op een rond beslag. Getuige het archaïsche pictogram voor ' $h u$ ' (zie de tabel) ontbreekt het bijbehorende deksel.

Op twee plaatsen, in lijn met het ringbeslag, is aan een breuk in het reliëf van de 'gevlochten' banden af te lezen dat de gietvorm voor dit vat uit twee helften bestond. (Op de gladde delen zijn de onregelmatigheden van de gietnaad weggepolijst). Maar interessanter nog zijn de zwakke verticale lijntjes die elders ook hier en daar op het vlechtwerk te zien zijn. Die geven namelijk aan dat dit patroon geproduceerd is door middel van aan de binnenzijde van de gietvorm ingemonteerde, pasklare reepjes klei, van te voren in veelvoud 'gestempeld' met een steeds herhaalde sectie van het vlechtreliëf. Een gebruikelijke techniek in deze tijd. Opgravingen bij Houma (in de toenmalige staat Jin en de huidige provincie Shanxi) hebben de werkplaats blootgelegd van een kolossale bronsgieterij waar overal op het terrein de resten van deze productiemethode verspreid lagen. Van talloze ornamenten die op Chinese bronzen in musea over de hele wereld aan te wijzen zijn, werden hier de exact passende klei-modellen gevonden, zowel in positief als negatief. ${ }^{15}$ Het is heel wel mogelijk dat dit vat in Houma is gemaakt. 
DE VELDEN BINNEN de vlechtranden zijn gedecoreerd met inlegwerk, in twee variaties: rond de hals en in het onderste register ligt een simpele krans van hartvormige schilden (de punten respectievelijk naar boven en naar beneden wijzend) in dunne, regelmatige lijnen, ingelegd met koper. De middelste registers daarentegen zijn gevuld met een ingewikkelder patroon, eveneens lineair maar met meer 'dik-en-dun' aangezet. Het is een open raster van vierkante haken, zoiets als de hoofdletter $\mathrm{T}$, in drie verspringende rijen en onderling verbonden. De lijnen van dit T-patroon zijn eveneens met koper ingelegd, maar hier is bovendien, steeds in het krulletje dat de bovenbalk van de $T$ afsluit, nog een extra accent geplaatst - in goud: een fijne 'komma' van goud, ingelegd in het koper.

INLEGWERK WERD IN de Oostelijke Zhou populair - althans in vaatwerk, in wapens wordt het al veel eerder gezien. De meningen verschillen over hoe deze 'mode' is ontstaan. Invloed uit het Westen, via de Noordelijke steppevolken doorgegeven, is één mogelijkheid. ${ }^{16}$ Maar de patronen kunnen ook een poging zijn om de veelkleurige en rijke uitstraling te benaderen van het lakwerk (vooral uit zuidelijker streken bekend: uit de staat Chu, rond Changsha in Midden China). Bovendien, in deze tijd van veel concurrerende staten en staatjes, zullen de verschillende hoven getracht hebben elkaar de loef af te steken in pracht en praal of exclusiviteit.

Dat alles gezegd zijnde, wordt tegenwoordig echter gedacht dat het inlegwerk in dit vat misschien wel eens een veel latere toevoeging zou kunnen zijn, en dat is niet zo onmogelijk als het lijkt. In elite-kringen van later eeuwen (vanaf de Song, ca 1 le eeuw en later) ging een grote fascinatie voor het verzamelen van 'oudheden' gepaard met een geringe kennis van de historische werkelijkheid. Zo was er bijvoorbeeld een hardnekkig idee dat alle brons van de (tot nu toe nog steeds legendarische) Xia-dynastie, voorgangers van de Shang, met goud was ingelegd. Hoopvolle 'vervalsingen' in die richting, al dan niet met kwade opzet, zijn inmiddels ook regelmatig herkend als zodanig. ${ }^{17}$

Wat nu deze $h u$ betreft, is er ten eerste van een dergelijke 'dubbele' inleg (goud in koper in brons ) geen enkel ander voorbeeld bekend; de gouden komma's zouden dus als eerste afvallen, als niet-origineel. Maar ook over het T-patroon wordt getwijfeld, omdat hier twee verschillende patronen door elkaar gehaald lijken te zijn, waarbij een van de twee bovendien uitsluitend in gegoten reliëf voorkomt. ${ }^{18}$ Daarentegen zijn er meerdere $h u$ bekend van vergelijkbare vorm en afmeting, en met dezelfde vlechtbanden, die geen inlegwerk bevatten.

In de eigen museumvitrine staat er ook zo een (die zijn deksel nog bezit: AK-MAK-1267). Niet ingelegd, maar wel met dezelfde gevlochten banden. Een opvallend verschil met de Sackler-kruik is de voet: in plaats van het omvangrijke voetstuk op tijger-steunen, hier alleen een lage voetring in de vorm van een vijfde vlechtrand. Interessant in dat licht is misschien dat de bronslegering van het hoge voetstuk in onderzoek gebleken is af te wijken van de rest van het vat, met een aanzienlijk hoger loodgehalte.

\section{Veranderend geloof}

ALLE ZEVEN TENTOONGESTELDE vaten zijn grafgaven, maar de voorgaande, oudste vijf waren rituele offervaten, terwijl de twee latere voorbeelden die nu volgen, uit de Han-dynastie (206 v.Chr.-220nnoChr), feerder overeenkomen3 12:59:54PM 


\section{Afbeelding 6}

Bronzen platte veldfles, bian hu, met hengsels, China, W. Han dynastie, re eeuw v.Chr., $27,0 \times 27,0 \times 11,6 \mathrm{~cm}$. Arthur M. Sackler Gallery of Art, Smithsonian Institution, Washington D.C., schenking van Arthur M. Sackler. S1987.14.

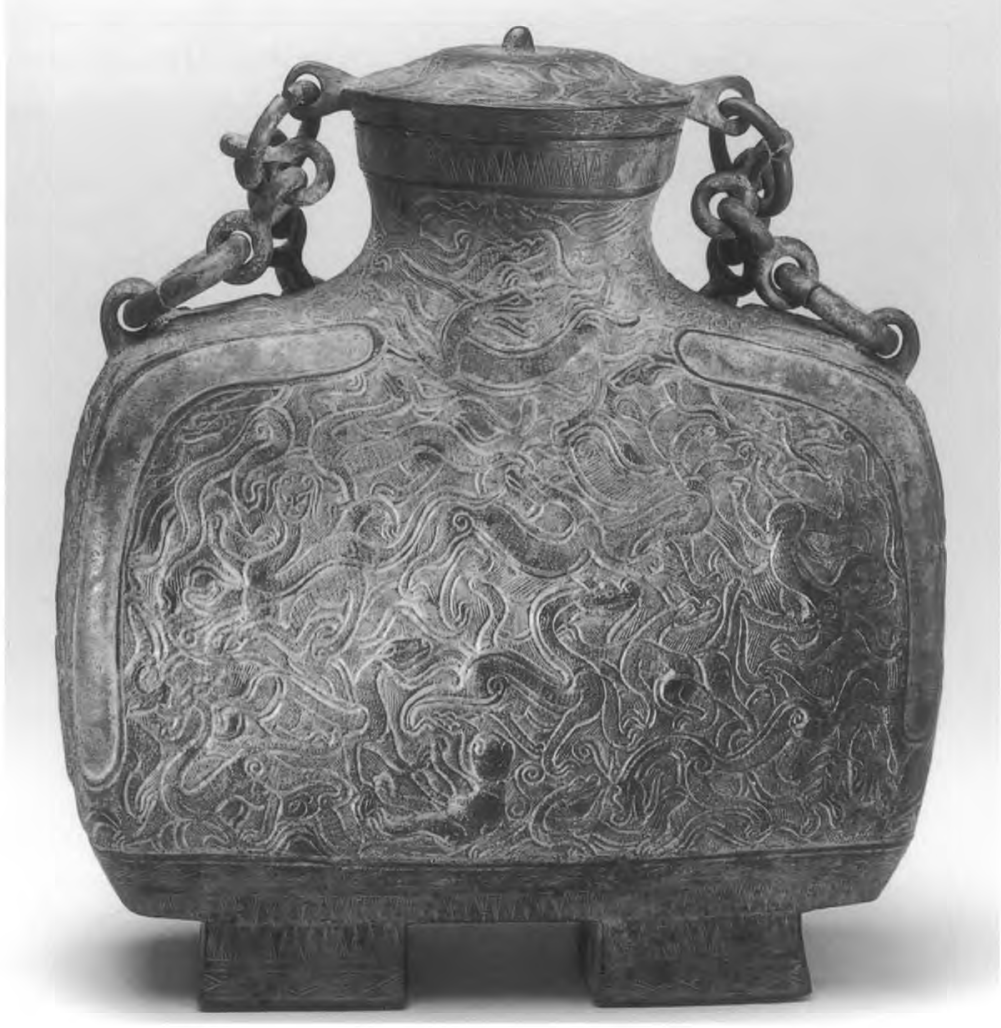

met alledaagse gebruiksvoorwerpen - in een chique, ònalledaagse, dus min of meer geritualiseerde uitvoering. Met andere woorden, ze weerspiegelen een omslag in het geloof, die naar men denkt in de tweede helft van de Oostelijke Zhou moet hebben plaatsgevonden. Het resultaat was dat in de inhoud van de graven de nadruk zich geleidelijk heeft verlegd - van het bijzetten van de instrumenten voor de tot dan toe allesoverheersende voorouderverering (de offervaten), naar het verschaffen van adequate voorzieningen voor een (eigen) leven na de dood.

- Bronzen platte veldfles, bian hu, met ketting-hengsel (afb. 6)

Westelijke Han dynastic (206 v.Chr.-9 n.Chr.), le eeuw v.Chr.

DEZE 'VELDFLES' IS groot, veel groter dan de bescheiden padvindersuitrusting die door de benaming wordt gesuggereerd, en de decoratie is verrassend rijk. ${ }^{19}$ De scènes op beide zijden van het vat demonstreren direct de preoccupatie met het hiernamaals in deze tijd: het is een fantastisch 'paradijs'-landschap, verblijfplaats van onsterfelijken. Afgezien van een paar smalle randjes onder en boven, met een simpel gegraveerd zaagtandmotief, zijn de vlakke zijden van het vat geheel hiermee gevuld, in twee panelen. Binnen de gladde 'schouderstukken' die de panelen scheiden - rond de hals loopt de decoratie door - is het een warreling van alle mogelijke diervormen in een wilde natuur. Op het eerste gezichtdijktohetdeenonderwaterscènermet 12:59:54PM 


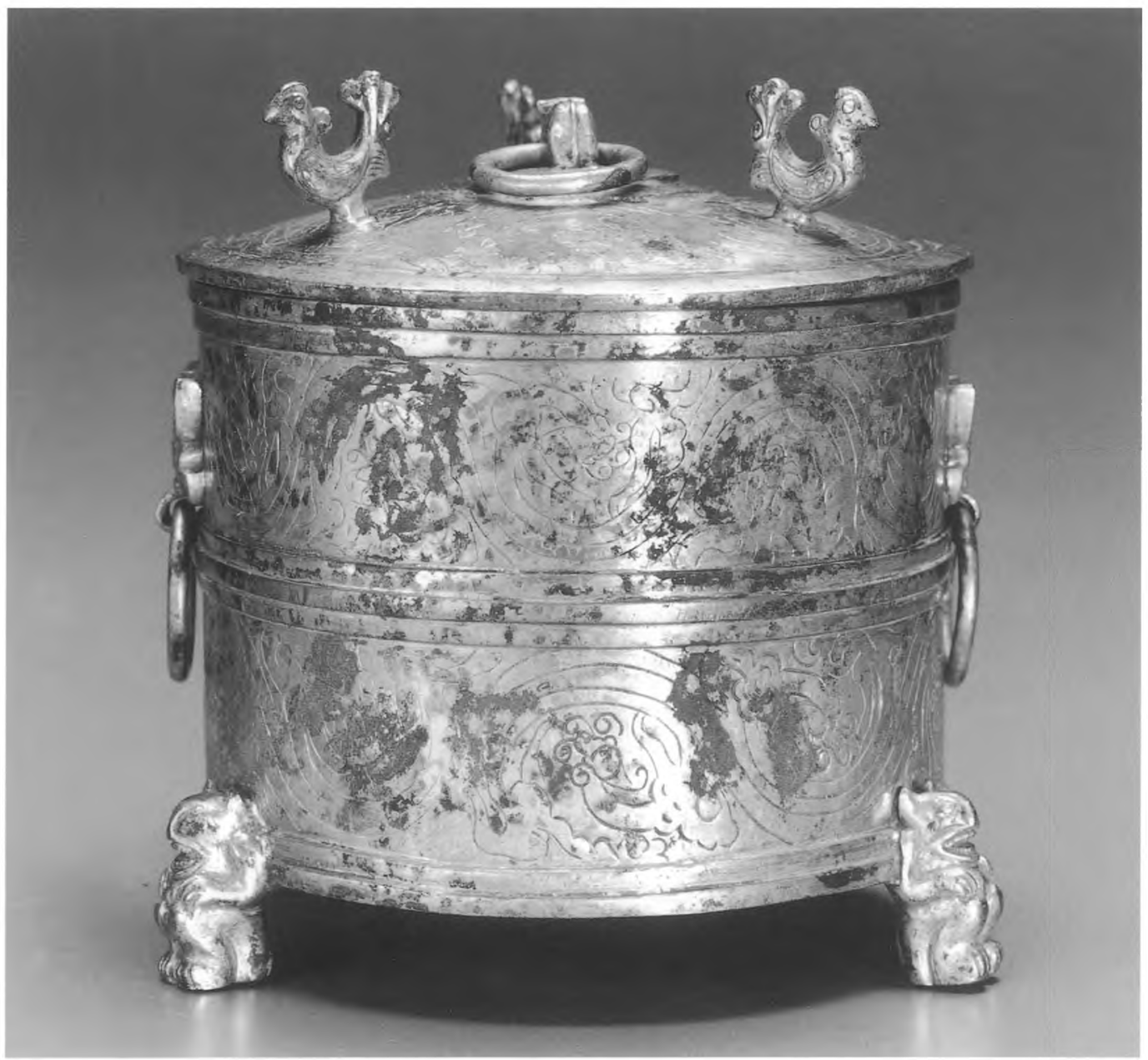

\section{Afbeelding 7}

Verguld bronzen ronde cosmetica-doos met deksel, lian, China, Han dynastie, re eeuw v.Chr,-le eeuw n.Chr., $13,0 \times 13,4 \times 13,6 \mathrm{~cm}$. Arthur M. Sackler Gallery of Art, Smithsonian Institution, Washington D.C., schenking van Arthur M. Sackler. S1987.341. inktvissen en zeeslangen, maar als je wat beter kijkt wordt de legpuzzel van vormen steeds duidelijker, en blijken alle 'tentakels' en 'hydra's' de ledematen van het een of andere dier te zijn: lopende draken met lange nekken, alert rondkijkende tijgers of wilde honden op hoge poten, en fantastisch bepluimde vogels, dat alles in een omlijsting van golfjes, die ook geen water maar schematische 'bergen' voorstellen. Een kleine selectie van de zelfde dieren loopt, minder verwarrend, in processie rond het gladde deksel - wat soms helpt om, heen en weer kijkend, een zijpaneel-bewoner te identificeren. De rijkdom wordt nog vergroot door het feit dat de voorstellingen op de twee kanten niet, zoals verwacht, hetzelfde zijn, maar totaal verschillend.

HET RELIËF SCHIJNT in grote lijnen eerst gegoten en daarna met de hand verder bijgewerkt en gedetailleerd te zijn - zie bijvoorbeeld ook de fijne stippeling en arcering, die de afzonderlijke figuren een eigen t'kleur' geven.3 12:59:54PM 
Dat de vormen van de lichamen van een deel van de dieren bol (gegoten)

zijn, onderscheidt dit vat van andere met soortgelijke warrelende diermotieven uit dezelfde tijd, die uitsluitend lineair, met ingesneden lijnen zijn vormgegeven. ${ }^{20}$

De sikkelvormige greep van het hengsel, op de afbeelding helaas niet zichtbaar, eindigt aan beide zijden in een gemeen-loerende roofdierkop, de puntige oren plat naar achteren gelegd, die met wijd opengesperde bek de eerste schakel van de ketting tracht te verslinden. De kettingen verbinden de twee ogen op de schouders van het vat met de twee aan weerszijden van het deksel

DE vORM VAN de platte 'veldfles' wordt voor het eerst gezien in de late Zhou, rond de 4 e eeuw v.Chr., en is tot ver in de Han toegepast. Ze wordt geacht ontleend te zijn aan het drinkgerei van Noordelijke (steppe) ruiters, maar de decoratie van dit vat plaatst het in een groep (zie weer noot 20) die waarschijnlijk uit de zuidelijkste provincies van China afkomstig is.

\section{- Verguld bronzen ronde cosmeticadoos met deksel, lian (afb. 7)}

Han-dynastie (206 v.Chr.-220 n.Chr.), le eeuw v.Chr.-le eeuw n.Chr.

HET KISTJE STEUNT op drie gehurkt zittende beertjes - of eerder kleine monstertjes, met een scherpe bek vol tanden. Het berenjong staat bovenop het deksel en oogt mollig en onschuldig, het fungeert als ringhouder (beter te zien in de afbeelding, vanuit een andere hoek, bij het tentoonstellingsbericht in het vorige nummer). Drie vogeltjes, op gelijke afstanden rond de ringgreep op het deksel geplaatst, kunnen misschien het - afgenomen en omgedraaide - deksel als pootjes ondersteunen, zoals ook bij andere vaten wel de bedoeling is. ${ }^{21}$ In dit geval lijkt dan echter de loshangende ring in de weg te zitten.

De decoratie, in twee registers rond de zijkanten van het vat en in een enkele rand rond het deksel, bestaat uit wervelende wolkenslierten (of waarschijnlijk $q i$, 'levenskracht', een materie die bijdraagt tot onsterfelijkheid). Aan twee zijden is in het bovenste register een ringhouder bevestigd in de vorm van een monsterkop. De qi-slierten zijn simpel gegraveerd, het geheel verguld. Met andere woorden: een fraai en luxueus ogend resultaat met betrekkelijk weinig moeite of ambachtelijke vaardigheid - vergeleken met het gegoten reliëf of de inlegtechnieken van Shang en Zhou.

Dergelijke ronde kistjes met deksel, een model dat ook in aardewerk bekend is, bevatten vaak een ronde bronzen spiegel, kammetjes, kwastjes en cosmetica.

\section{Noten}

1. De bronzen wiggen (chaplets) zijn vaak zichtbaar in het oppervlak van het voltooide brons als kleine 'eilandjes' van afwijkende kleur, doordat de legering van het afvalstukje niet noodzakelijk dezelfde was als die van het brons voor het vat.

2. Gepubliceerd in: Veilingcatalogus Christie's, Londen, 12 October 1970 (lot 106); D.H. Delbanco, Art from Ritual: Ancient Chinese Bronze Vessels from the Arthur $M$. Sackler collections, Cambridge en Washington, 1983 (no. 21); Thomas Lawton et al. 
Institution, Washington D.C., 1987, pp. 154-155; Robert W. Bagley, Shang Ritual Bronzes in the Arthur M. Sackler Collections, Harvard University Press, Cambridge, Mass., 1987, pp. $428-435$ (no. 77).

3. De vorm van de inscriptie moet dus in spiegelbeeld en in hoogreliëf op de onderzijde van de kern zijn aangebracht. Soms is aan sporen van een naad te zien dat dit gebeurde d.m.v. een ingezet stukje klei. Waarschijnlijk werd dat blokje bestempeld met een (gemakkelijker te maken) 'normaal' en verdiept ingesneden teken.

4. Graf E9 bij de grote tombe WKGM1 in Wuguancun bij Anyang. Zie Bagley, op. cit., p. 430.

5. Gepubliceerd in: Bagley, op. cit., pp. 484-485 (no. 92). (Inscriptie:) Noel Barnard and Cheung Kwong-yue, Rubbings and Hand Copies of Bronze inscriptions in Chinese, Japanese, European, American and Australasian Collections. Yee Wen Publ., Taibei, 1978, p. 879.

6. Gepubliceerd in: Jessica Rawson, Western Zhou Ritual Bronzes from the Arthur M. Sackler Collections, Harvard University Press, Cambridge, Mass., 1990, pp. 368-369 (no. 39).

7. Zie Rawson, op. cit., pp. 22-23, en figs. 21, 25, 27.

8. Dat geldt vooral voor ding en gui voedselvaten, het wijngerei verdwijnt grotendeels, zoals gezegd.

9. In de Sumitomo Collectie in Kyoto (Shinshû Sen'oko Seishô, Kyoto, 1971, Vol. 2 , no. 29), en in het Nationaal Paleismuseum, Taiwan (Gugong tongqi tulu, Taibei 1958, Vol. 2, 1.74).

10. Zie Rawson, op. cit., p. 101 fig. 143b, voor een tekening van een vrijwel identiek type, eveneens late Westelijke Zhou, in twee gelijke 'stellen', van drie en vijf stuks de laatste met gelijke inscriptie.

11. Zie ook Rawson, op. cit., pp. 105-109.

12. Gepubliceerd in: Cheng Te-k'un, Archaeology in China, Vol. III, Chou China, Cambridge 1963, pl. 19b.

13. Rawson, op. cit., toont in de inleiding (p. 110 en fig. 152) een enigszins vergelijkbare, ook 'platte' he (met cirkelvormig zijaanzicht). Zij meent dat dit wellicht een vertaling in brons kan zijn van een oorspronkelijk in hout uitgevoerd model.

14. Gepubliceerd in: W.Thomas Chase, Ancient Chinese Bronze Art: Casting the Precious Sacral Vessel, China Institute, New York, 1991, pp. 67-68 (no. 30), pl. VI; Jenny So, Eastern Zhou Ritual Bronzes from the Arthur M. Sackler Collections, Abrams, New York, 1995, pp. 52-55 (no. 43).

15. Zie bijvoorbeeld: Art of the Houma Foundry, Princeton 1996; en: Robert W. Bagley, 'What the Bronzes from Hunyuan Tell Us about the Foundry at Houma', Orientations, January 1995, pp. 46-54.

16. Die steppe-invloed zou ook kunnen gelden voor de gevlochten koorden rond het vat: een imitatie van een draagbare kruik, zoals ook de bianhu no. 6 er een is.

17. Zie William Watson, 'On some Categories of Archaïsm in Chinese Bronzes', Ars Orientalis 9 (1973), pp. 1-13.

18. Zie Jenny So, op. cit., p. 254.

19. Gepubliceerd in: Jan Fontein en Wu Tung, Unearthing China's Past, Museum of Fine Arts, Boston Mass., 1973 (no. 55); Thomas Lawton, op. cit., p. 234.

20. Zie Fontein, op. cit., afb. 52-54 en pp. 118-124 voor voorbeelden van dergelijke scènes.

21. Zie bijvoorbeeld de hu in het Rijksmuseum, AK-MAK-282. 